\title{
Influence of characteristic types of thermal insulation on energy savings of AAC-based building envelope: a comparison
}

\author{
V. Kočí, J. Maděra \& R. Černý \\ Department of Materials Engineering and Chemistry, Faculty of Civil \\ Engineering, Czech Technical University in Prague, Czech Republic
}

\begin{abstract}
The energy efficiency calculations of several types of AAC-based building envelopes are presented in this paper. As boundary conditions, four different climates of Czech cities are chosen. The calculations are accomplished using Künzel's mathematical model of coupled heat and moisture transport implemented into computer simulation tool HEMOT. The main objective of this paper is to choose the best insulating material in order to reach maximal energy savings.

Keywords: AAC, energy efficiency, heat and moisture transport, computational simulation.
\end{abstract}

\section{Introduction}

Efforts to save energy nowadays have become evident in all the sectors of industry, in the building industry as well. The main reason for this fact is the permanent increase of energy prices, exhaustibility of traditional energy sources and the negative influence on the environment during their extraction.

Almost $40 \%$ of energy in EU is consumed in buildings; $57 \%$ of this amount on average is heating energy $[1,2]$. That means, almost one quarter of overall energy consumption is allotted to heating. So there is a lot of space where energy could be saved. One of the possibilities in how to reach this objective is to use more effective heating systems, build low energy houses or improve the thermal capabilities of the envelopes of old buildings. This is also the main subject of a new EU directive known as EPBD II (Energy Performance of Buildings Directive II) [3], which orders the obligation of construction of "near zero energy 
houses" no later than 2021. This directive has to be implemented into national thermal standards. In the Czech Republic, thermal standard CSN EN 730540 2: Thermal protection of buildings - Part 2: Requirements [4] was already modified in 2011 in order to meet the new requirements. Among the others, the overall U-value of building envelope should be between 0.12 and $0.18 \mathrm{~W} / \mathrm{m}^{2} \mathrm{~K}$.

To reach these values it will be necessary to use new materials with excellent thermal insulating properties or use sufficient thickness of thermal insulation. One of prospective materials is, among others, autoclaved aerated concrete (AAC). The value of thermal conductivity is about $0.1 \mathrm{~W} / \mathrm{mK}[5,6]$ or higher depending on moisture content, however the extensive research is there still running in order to improve not only thermal but also hygric and mechanical parameters using for the most part, waste products [7-12]. These modified materials could be used in single-layer masonry as far as they meet thermal requirements or better recommendations. But this will be very difficult so it can be assumed, the presence of thermal insulation will be still necessary.

In this paper the effect of several types of thermal insulation on energy savings of AAC-based building envelope under different climatic conditions is compared.

\section{Computational analysis}

The computer code HEMOT [13] is based on the general finite element package SIFEL [14]. As basic input parameters of the mathematical model, hygric, thermal and basic physical parameters of used materials, scheme of construction detail, initial and boundary conditions and time specification of simulation are required. Description of all input parameters in more detail is given later.

In the computer simulations we focused on a comparison of energy efficiency of several building envelopes based on AAC provided with different thermal insulating materials.

\subsection{Mathematical model}

Künzel's mathematical model of heat and moisture transport [15] was used in the simulations which can be formulated as

$$
\begin{gathered}
\frac{d \rho_{v}}{d \varphi} \frac{\partial \varphi}{\partial t}=\operatorname{div}\left[D_{\varphi} \operatorname{grad} \varphi+\delta_{p} \operatorname{grad}\left(\varphi p_{s}\right)\right] \\
\frac{d H}{d T} \frac{\partial T}{\partial t}=\operatorname{div}(\lambda \operatorname{grad} T)+L_{v} \operatorname{div}\left[\delta_{p} \operatorname{grad}\left(\varphi p_{s}\right)\right]
\end{gathered}
$$

where $\rho_{v}$ is the partial density of moisture, $\varphi$ relative humidity, $\delta_{p}$ permeability of water vapour, $p_{s}$ partial pressure of saturated water vapour, $H$ enthalpy 
density, $L_{v}$ heat of evaporation of water, $\lambda$ thermal conductivity and $T$ temperature,

$$
D_{\varphi}=D_{w} \frac{d \rho_{v}}{d \varphi}
$$

is liquid moisture diffusivity coefficient, $D_{w}$ capillary transport coefficient.

\subsection{Scheme of construction detail}

Five variations of building envelope based on AAC were chosen for simulation. As a start-up building envelope we chose AAC without any thermal insulation, only with external and internal finishes which allowed us to get real image about energy efficiency of simple AAC building envelope (marked as I). In the next simulations we provided AAC with hydrophilic mineral wool (II), hydrophobic mineral wool (III), expanded polystyrene (IV) and Multipor Ytong produced by Xella CZ (V). All these envelopes were provided from interior and exterior side with Baumit MVR Uni plaster which is recommended for AAC structures as external finish. On the material interface between mineral wool and AAC an adhesive mortar layer was placed. Description of used materials in more detail is given in next subsection. Scheme of construction detail including the dimensions of each layer is shown in Figure 1.

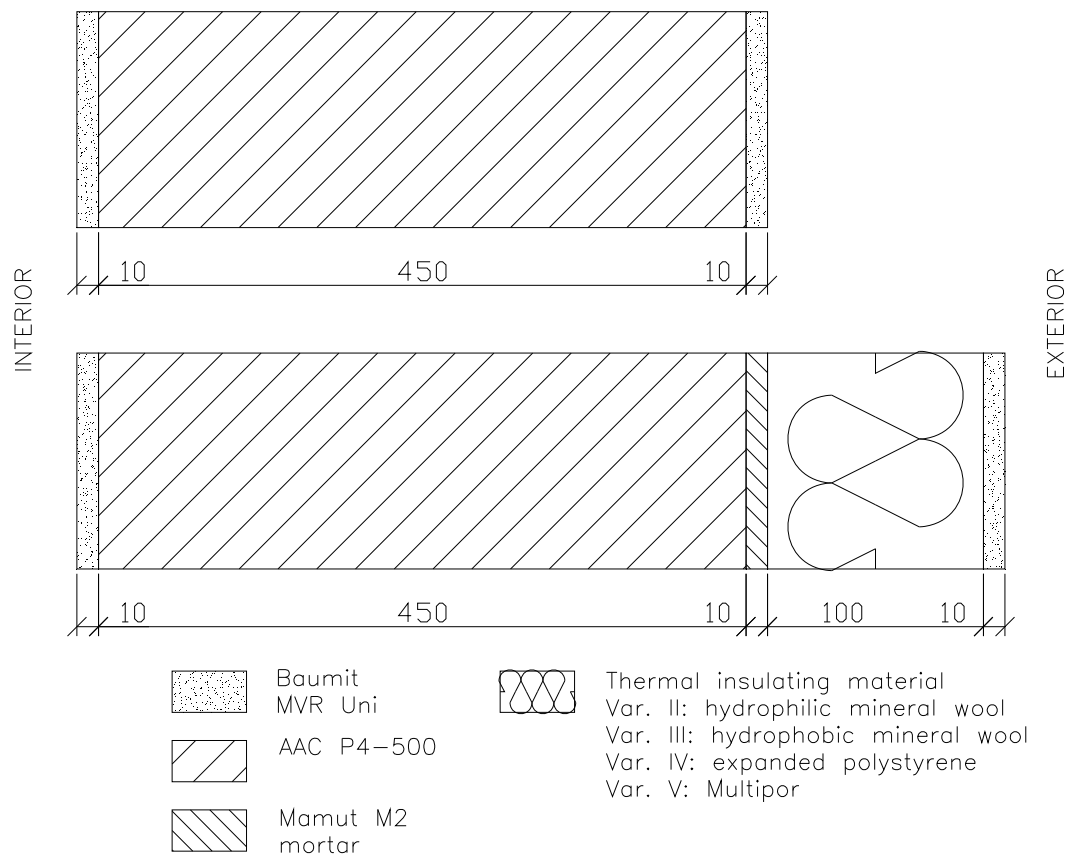

Figure 1: $\quad$ Scheme of AAC-based building envelope. 


\subsection{Material parameters}

Autoclaved aerated concrete P4-500 produced by Xella CZ was under consideration in this paper as the load-bearing material. For exterior and interior renders we used Baumit MVR Uni Plaster, which is single-layer plaster for exterior and interior surfaces especially recommended for AAC. As the thermal insulation we assumed Rockwool hydrophilic mineral wool, hydrophobic mineral wool, expanded polystyrene and Multipor. For adhesive layer between AAC and mineral wool we used Mamut M2 mortar.

All the material parameters were measured in laboratory of transport processes at the Department of Materials Engineering and Chemistry, Faculty of Civil Engineering, Czech Technical University in Prague [16-18] and are summarized in Tables 1 and 2 . We used these symbols: $\rho-$ bulk density $\left[\mathrm{kg} / \mathrm{m}^{3}\right]$, $\rho_{\text {mat }}-$ matrix density $\left[\mathrm{kg} / \mathrm{m}^{3}\right], \psi$ - porosity $[\%], c-$ specific heat capacity $[\mathrm{J} / \mathrm{kgK}], \mu-$ water vapour diffusion resistance factor $[-], w-$ moisture content by volume $\left[\mathrm{m}^{3} / \mathrm{m}^{3}\right], \lambda-$ thermal conductivity $[\mathrm{W} / \mathrm{mK}], \kappa_{a p p}-$ moisture diffusivity $\left[\mathrm{m}^{2} / \mathrm{s}\right]$.

Table 1: $\quad$ Material characteristics - Part I.

\begin{tabular}{|c|c|c|c|}
\hline Parameter & AAC P4-500 & Mamut M2 mortar & $\begin{array}{c}\text { Baumit MVR Uni } \\
\text { plaster }\end{array}$ \\
\hline$\rho\left[\mathrm{kg} \mathrm{m}^{-3}\right]$ & 500 & 1430 & 1402 \\
\hline$\psi[\%]$ & 80.2 & 42.6 & 44.4 \\
\hline$c\left[\mathrm{~J} \mathrm{~kg}^{-1} \mathrm{~K}^{-1}\right]$ & $1020-1510$ & 1020 & $1020-1780$ \\
\hline$\mu[-]$ & $3.0-9.7$ & 12.4 & $4.5-12.4$ \\
\hline$\lambda_{d r v}\left[\mathrm{~W} \mathrm{~m}^{-1} \mathrm{~K}^{-1}\right]$ & 0.114 & 0.481 & 0.443 \\
\hline$\lambda_{s a t}\left[\mathrm{~W} \mathrm{~m}^{-1} \mathrm{~K}^{-1}\right]$ & 0.454 & 2.022 & 1.380 \\
\hline$\kappa_{a p p}\left[\mathrm{~m}^{2} \mathrm{~s}^{-1}\right]$ & $5.82 \mathrm{e}-8$ & $1.07 \mathrm{e}-9$ & $1.59 \mathrm{e}-9$ \\
\hline$w_{h v g}\left[\mathrm{~m}^{3} \mathrm{~m}^{-3}\right]$ & 0.01846 & 0.0201 & 0.042 \\
\hline
\end{tabular}

Table 2: $\quad$ Material characteristics - Part II.

\begin{tabular}{|c|c|c|c|c|}
\hline Parameter & $\begin{array}{c}\text { Hydrophilic } \\
\text { mineral wool }\end{array}$ & $\begin{array}{l}\text { Hydrophobic } \\
\text { mineral wool }\end{array}$ & $\begin{array}{c}\text { Expanded } \\
\text { polystyrene }\end{array}$ & Multipor \\
\hline$\rho\left[\mathrm{kg} \mathrm{m}^{-3}\right]$ & 71 & 270 & 50 & 125 \\
\hline$\psi[\%]$ & 96.0 & 88.0 & 97.0 & 94.2 \\
\hline$c\left[\mathrm{~J} \mathrm{~kg}^{-1} \mathrm{~K}^{-1}\right]$ & 810 & 630 & 1300 & $2230-3500$ \\
\hline$\mu[-]$ & 4.3 & 3.0 & 50 & $1.9-10.9$ \\
\hline$\lambda_{d r y}\left[\mathrm{~W} \mathrm{~m}^{-1} \mathrm{~K}^{-1}\right]$ & 0.043 & 0.045 & 0.040 & 0.047 \\
\hline$\lambda_{\text {sat }}\left[\mathrm{W} \mathrm{m}^{-1} \mathrm{~K}^{-1}\right]$ & 0.246 & 0.246 & 0.560 & 0.166 \\
\hline$\kappa_{a p p}\left[\mathrm{~m}^{2} \mathrm{~s}^{-1}\right]$ & $8.4 \mathrm{e}-6$ & $2.51 \mathrm{e}-10$ & $2.10 \mathrm{e}-11$ & $3.26 \mathrm{e}-9$ \\
\hline $\begin{array}{c}w_{\text {hyg }} \\
{\left[\mathrm{m}^{3} \mathrm{~m}^{-3}\right]}\end{array}$ & 0.000046 & 0.0073 & 0.001 & 0.0078 \\
\hline
\end{tabular}




\subsection{Initial and boundary conditions and time interval of simulation}

As the initial and boundary conditions (Figure 2) climatic data in the exterior in the form of Test Reference Year (TRY) for Prague, Liberec, Brno and Hradec Kralove were used. TRY contains average data for 30 years of temperature, relative humidity, rain, wind velocity and direction and solar radiation. On the interior side constant value of relative humidity $55 \%$ and temperature $21^{\circ} \mathrm{C}$ (see Fig. 2) was chosen. The simulation took 4 years in order to reach hygrothermal steady-state. The results are related to the last year.

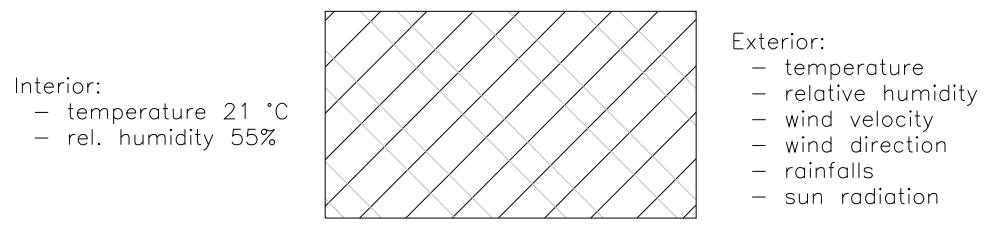

Figure 2: $\quad$ Boundary conditions.

\subsection{Energy efficiency calculations}

When the energy efficiency is evaluated, the results obtained in fifth year of simulation are taken into account. At first, the heat fluxes in boundary elements of building envelope cross-section are calculated according to the relation

$$
q=-\lambda \frac{d T}{d x}
$$

where $q$ denotes the heat flux [W/ $\mathrm{m}^{2}$ envelope $], \lambda$ is thermal conductivity depending on moisture content $[\mathrm{W} / \mathrm{mK}], d T$ is difference between temperatures of two nodes defining the element $[\mathrm{K}]$ and $d x$ is size of the element [m].

The value of thermal conductivity is determined from calculated moisture content according to the linear function characterized by values of $\lambda_{d r y}$ and $\lambda_{\text {sat }}$ in Table 1 of Baumit MVR Uni plaster.

The energy efficiency per annum can be then calculated as integral of time function of heat flux according to the relation

$$
Q=\int_{1 \text { Jan }}^{31 D e c} q(t) d t,
$$

where $Q$ denotes the energy efficiency per annum $\left[\mathrm{kWh} / \mathrm{m}^{2}\right.$ envelope $\left.\mathrm{a}\right]$ and $q(t)$ is time function of heat flux [W/ $/ \mathrm{m}^{2}$ envelope].

\section{Computational results}

The energy efficiency of presented building envelopes was calculated on the interior side because of more steady values of heat fluxes which are not affected 


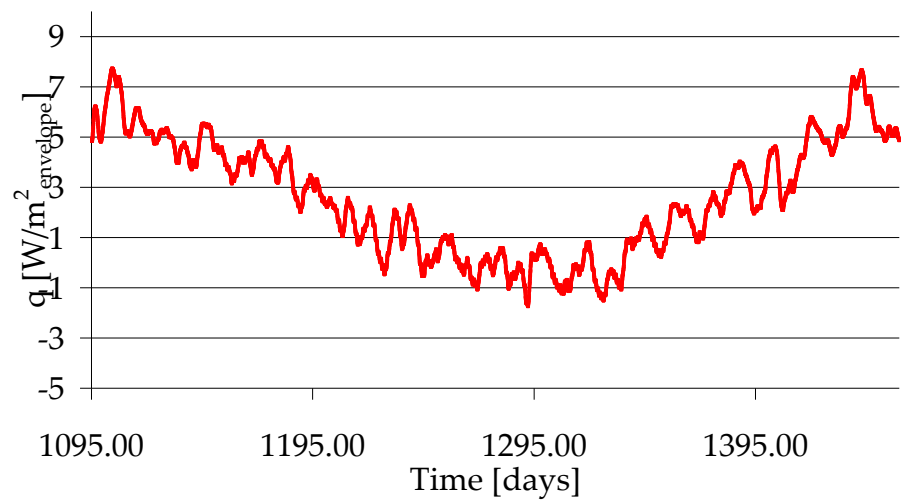

Figure 3: Heat flux on interior side, Brno, without thermal insulation.

by climatic conditions as much as on the exterior side. The evaluation has been accomplished in the fifth year of simulation $\left(1095^{\text {st }}-1460^{\text {th }}\right.$ day).

Figures 3-7 show hourly values of heat flux on interior side of several building envelope. The figures are very similar so only the representatives are chosen. Figure 3 shows the hourly values of heat flux on interior side of building envelope without any insulation under Brno's climatic conditions, Figure 4 shows values of heat flux of building envelope provided with hydrophilic mineral wool under Prague's climatic condition. Figure 5 shows values of heat flux of building envelope provided with hydrophobic mineral wool under Hradec Kralove's climatic condition, Figure 6 shows values of heat flux of building envelope provided with expanded polystyrene under Liberec' climatic condition and Figure 7 shows values of heat flux of building envelope provided with Multipor under climatic condition of Prague.

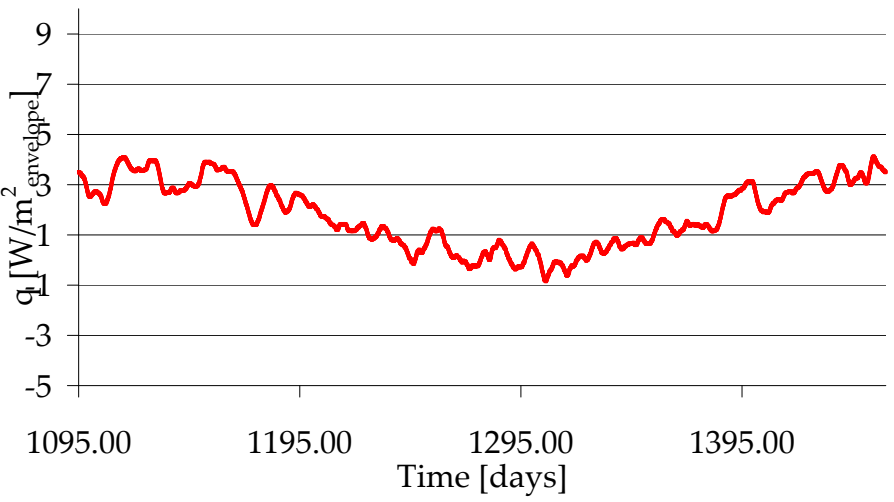

Figure 4: Heat flux on interior side, Prague, hydrophilic mineral wool. 


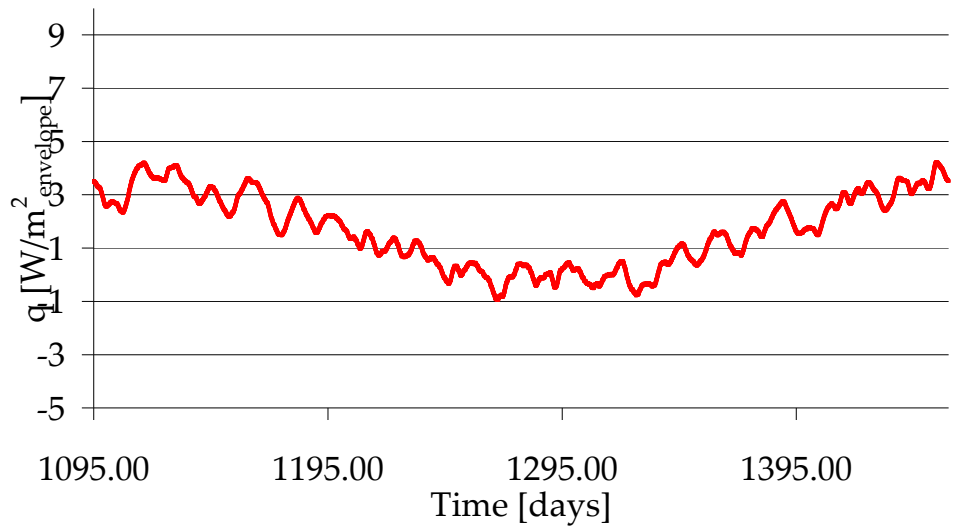

Figure 5: Heat flux on interior side, Hradec Kralove, hydrophobic mineral wool.

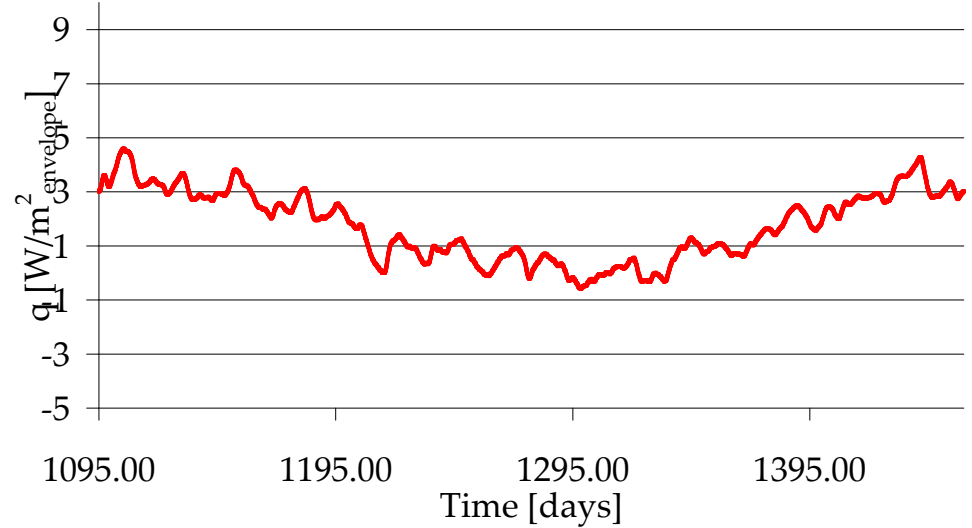

Figure 6: Heat flux on interior side, Liberec, expanded polystyrene.

When the heat fluxes were calculated, the values of thermal conductivity on interior side depending on moisture content were used. These values differ only a bit because the moisture content on the interior side is almost stable. Figure 8 shows values of thermal conductivity on interior side of building envelope provided with hydrophobic mineral wool. Figure 9 shows values of thermal conductivity on interior side under Prague's climatic conditions. 


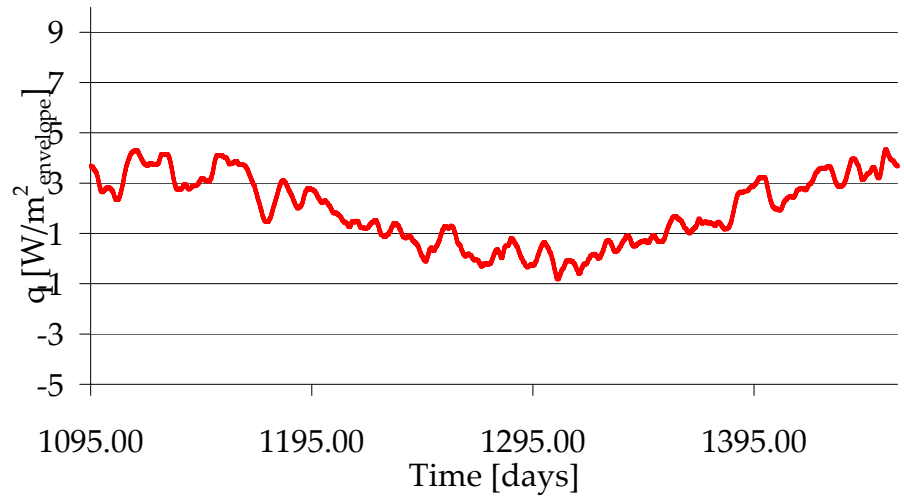

Figure 7: Heat flux on interior side, Prague, Multipor.

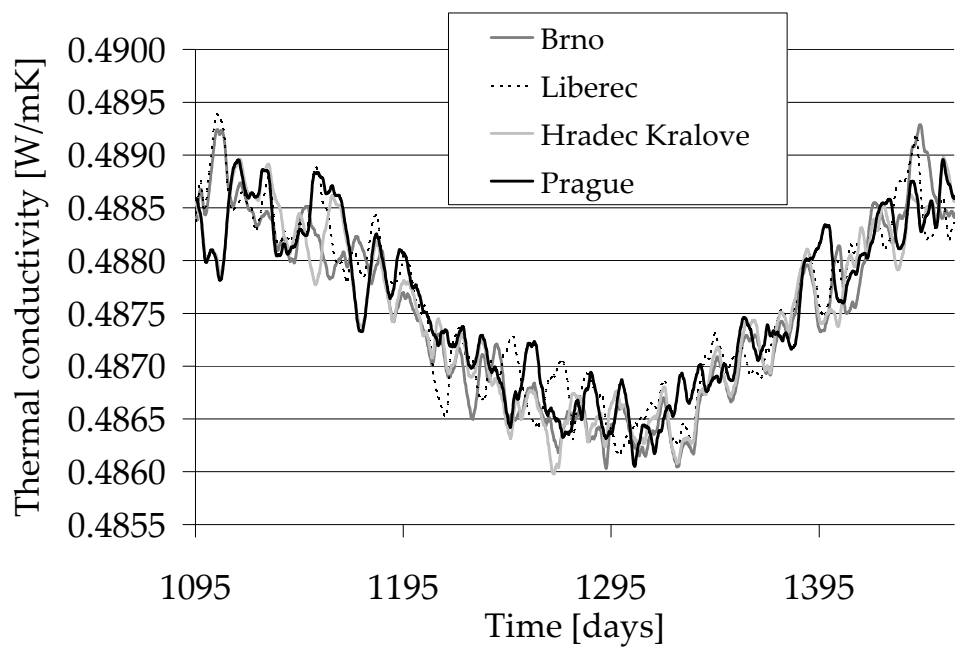

Figure 8: Values of thermal conductivity of building envelopes provided with hydrophobic mineral wool. 


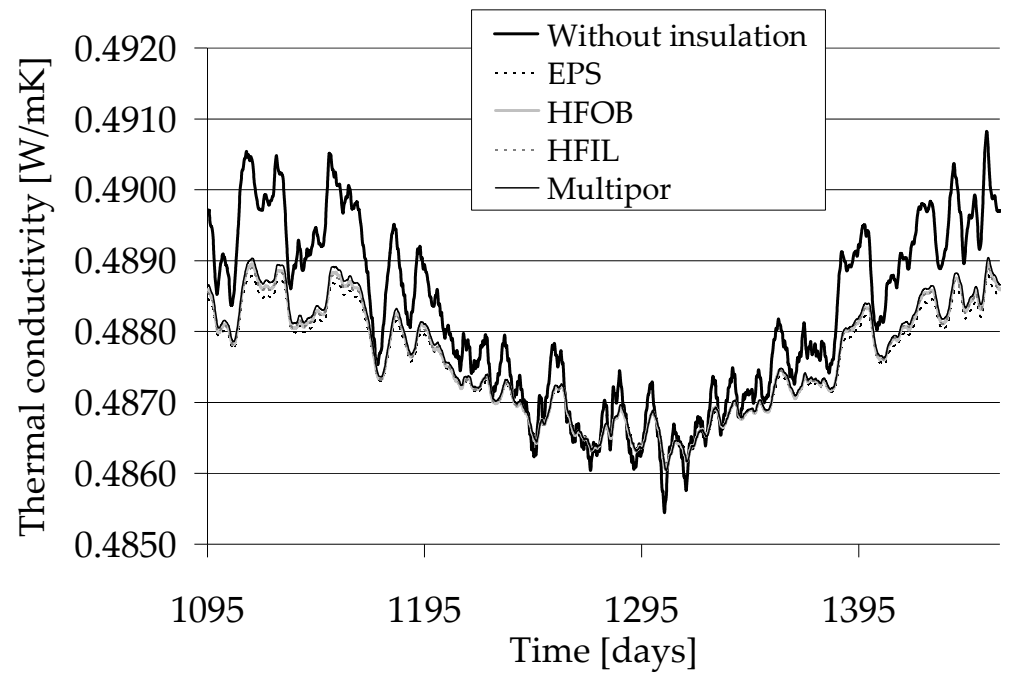

Figure 9: Values of thermal conductivity of building envelopes under Prague's climatic conditions.

The energy efficiency per annum given by integral of time function of heat flux is summarized in Table 3. We obtained two values, on interior and exterior side. Because the calculations were accomplished in non-steady state, these values are different. This is caused by heat accumulation inside the building envelope. As the decisive values we assumed the results on interior side which is not as affected by hourly climatic changes as the exterior side.

Table 3: Energy efficiency results $\left[\mathrm{kWh} / \mathrm{m}_{\text {envelope }}^{2}\right]$.

\begin{tabular}{|c|c|c|c|c|}
\hline & Brno & Hradec Kralove & Liberec & Prague \\
\hline Without thermal insulation & 22.715 & 22.813 & 25.150 & 24.900 \\
\hline Expanded polystyrene & 13.699 & 13.786 & 15.198 & 15.046 \\
\hline Hydrophobic mineral wool & 14.470 & 14.558 & 16.044 & 15.895 \\
\hline Hydrophilic mineral wool & 14.353 & 14.443 & 15.933 & 15.782 \\
\hline Multipor & 15.018 & 15.097 & 16.642 & 16.486 \\
\hline
\end{tabular}

\section{Discussion}

The results presented in this paper show that energy efficiency of building envelope depends on its composition and on climatic conditions which it is exposed to.

Within the frame of this research, four different towns have been chosen, namely Prague, Brno, Liberec and Hradec Kralove, which have different position and altitude. The relatively worst climatic conditions have Prague and Liberec, which was confirmed comparing energy balance of identical building envelopes. 
Whereas the thermal properties within the investigated insulating materials are almost identical in dry state, the moisture transport parameters differ significantly. Therefore the differences in energy efficiency can be expected. For instance, if moisture diffusivity is compared, it can be noticed, hydrophilic mineral wool differs almost up to 5 orders of magnitude from other thermal insulations and liquid moisture transport is then much faster. Furthermore, water vapor diffusion resistance factor of expanded polystyrene is up to 30 times higher than hydrophobic mineral wool and up to 25 times higher than hydrophilic mineral wool. It means, both types of mineral wool are easily vaporpermeable. This leads to increase of their moisture content and decrease of thermal insulating properties. However, it allows the construction to "breathe." As a result, the moisture accumulation from interior due to usage of building inside the envelope is eliminated. It is very important because of elimination of biological or mechanical corrosion. On the other hand, the certain forfeit for this is a slight increase of energy demand of building.

According to the results, expanded polystyrene seems to be the best thermal insulating material as it reduces the heating costs in comparison with noninsulated building envelope averagely by $39.6 \%$. Multipor reduced heating costs only by $33.8 \%$, hydrophobic mineral wool by $36.2 \%$ and hydrophilic mineral wool by $36.7 \%$.

It can be summarized from a point of view of energy savings that expanded polystyrene is the most advantageous material to be used in order to save the energy and environment as well. However, the extensive research of AAC based building envelopes proves, that hydrophilic mineral wool is one of the most considerate among the common insulating materials to applied external finish and positively affects the service life of the whole envelope [19].

\section{Conclusions}

In this paper, the energy efficiency of several types of building envelopes under different climatic conditions has been analyzed. The envelope consisted of AAC provided with four different types of thermal insulation, namely expanded polystyrene, hydrophobic and hydrophilic mineral wool and Multipor. Climatic conditions of Brno, Hradec Kralove, Liberec and Prague were assumed.

All the results presented in this paper were obtained using computationalexperimental approach of coupled heat and moisture transport. In comparison with Czech standards is this method more advantageous because presence of moisture content is not neglected and the results are then more accurate.

It was shown that the best choice from point of view of energy savings is expanded polystyrene, because it will reduce the heating costs by almost $40 \%$. However, it is important to realize, the energy efficiency is not the only single factor playing a role during the building envelope design. It is important to also take into consideration other factors such as durability. Otherwise the repair costs may exceed the costs saved on heating. 


\section{Acknowledgement}

This research has been supported by the Czech Ministry of Education, Youth and Sports, under project No SGS12/105/OHK1/2T/11.

\section{References}

[1] Chwieduk, D. Towards Sustainable-energy buildings. Applied Energy, 76, pp. 211-217, 2003.

[2] EuroACE, Towards Energy Efficient Buildings in Europe, final report June (ec.europa.eu), 2004.

[3] European Union, Directive 2010/31/EC of the European Parliament and of the Council of 19 May 2010 on the energy performance of buildings, Official Journal of the European Communities, 2010.

[4] CSN 73 0540-2. Thermal protection of buildings - part 2: Requirements, Czech Office for Standards, Metrology and Testing: Prague, 2011.

[5] Topcu, I.B., Uygunoglu, T. Properties of autoclaved lightweight aggregate concrete. Building and Environment, 42, pp. 4108-4116, 2007.

[6] Jerman, M., Kočí, V., Maděra, J., Výborný, J., Černý, R. Water and heat transport parameters of materials involved in AAC-based building envelopes, in 1st Central European Symposium on Building Physics. Lodz: Technical University of Lodz, pp. 39-45, 2010.

[7] Qiao, X.C., Ng, B.R., Tyrer, M., Poon, C.S., Cheeseman, C.R. Production of lightweight concrete using incinerator bottom ash. Construction and Building Materials, 4, pp. 473-480, 2008.

[8] Kurama, H., Topcu, I.B., Karakurt, C. Properties of the autoclaved aerated concrete produced from coal bottom ash. Journal of Materials Processing Technology, 2, pp. 767-773, 2009.

[9] Wongkeo, W., Chaipanich, A. Compressive strength, microstructure and thermal analysis of autoclaved and air cured structural lightweight concrete made with coal bottom ash and silica fume. Materials Science and Engineering, 16-17, pp. 3676-3684, 2010.

[10] Holt, E., Raivio, P. Use of gasification residues in aerated autoclaved concrete. Cement and Concrete Research, 4, pp. 796-802, 2005.

[11] Goual, M.S., Bali, A., de Barquin, F., Dheilly, R.M., Queneudec, M. Isothermal moisture properties of Clayey Cellular Concretes elaborated from clayey waste, cement and aluminium powder. Cement and Concrete Research, 9, pp. 1768-1776, 2006.

[12] Hauser, A., Eggenberger, U., Mumenthaler, T. Fly ash from cellulose industry as secondary raw material in autoclaved aerated concrete. Cement and Concrete Research, 3, pp. 297-302, 2009.

[13] Černý, R. Complex System of Methods for Directed Design and Assessment of Functional Properties of Building Materials: Assessment and Synthesis of Analytical Data and Construction of the System, CTU Prague, 2010. 
[14] Kruis, J. Koudelka, T., Krejčí, T. Efficient computer implementation of coupled hydro-thermo-mechanical analysis. Mathematics and Computers in Simulation, 80, pp. 1578-1588, 2010.

[15] Kuenzel, H. M., Simultaneous Heat and Moisture Transport in Building Components, Ph. D. Thesis. IRB Verlag, Stuttgart, 1995.

[16] Grunewald, J. DELPHIN 4.1 - Documentation, Theoretical Fundamentals, TU Dresden, Dresden. 2000.

[17] Jiřičková, M., Černý, R. Effect of Hydrophilic Admixtures on Moisture and Heat Transport and Storage Parameters of Mineral Wool. Construction and Building Materials, 20, pp. 425-434, 2006.

[18] Jerman, M., Maděra, J., Černý, R. Computational Modeling of Heat and Moisture Transport in a Building Envelope with Hydrophilic Mineral Wool Insulation, in Proc. of the 8th Symposium on Building Physics in the Nordic Countries. Lyngby: Technical University of Denmark, BYG.DTU, pp. 449456, 2008.

[19] Kočí, V., Výborný, J., Černý, R. Computational and Experimental Characterization of Building Envelopes Based on Autoclaved Aerated Concrete, Materials Characterization V Computational Methods and Experiments. Southampton: WIT Press, pp. 363-373, 2011. 